Research Article

\title{
Allozyme differentiation of two populations of the genus Neoplecostomus Eigenmann \& Eigenmann, 1888 (Teleostei, Loricariidae) from the upper Paraná River basin, Brazil
}

\author{
Ana Flávia Reusing ${ }^{1}$, Erasmo Renesto ${ }^{2}$, Fábio F. Roxo ${ }^{3}$ and Cláudio H. Zawadzki ${ }^{4}$ \\ ${ }^{1}$ Pós-Graduação em Genética e Melhoramento, Universidade Estadual de Maringá, Maringá, PR, Brazil. \\ ${ }^{2}$ Departamento de Biologia Celular e Genética/Nupélia, Universidade Estadual de Maringá, Maringá, \\ PR, Brazil. \\ ${ }^{3}$ Pós-Graduação em Ciências Biológicas, Laboratório de Biologia e Genética de Peixes, \\ Universidade Estadual Paulista "Júlio de Mesquita Filho", Botucatu, SP, Brazil. \\ ${ }^{4}$ Departamento de Biologia/Nupélia, Universidade Estadual de Maringá, Maringá, PR, Brazil.
}

\begin{abstract}
Allozyme electrophoresis was used to examine 12 enzymatic systems in two populations of the genus Neoplecostomus from the Paraná River basin. Samples of Neoplecostomus sp. 1 were collected in Paraitinguinha stream of the Tietê River basin, in the municipality of Salesópolis, São Paulo State, and those of Neoplecostomus sp. 2 from São Domingos stream of the Rio Grande River basin, in the municipality of Muzambinho, Minas Gerais State. The genetic variability of the two populations was estimated by Nei's expected heterozygosity and was considered lower than average for populations of freshwater fish. The proportion of polymorphic loci was low (only $5.26 \%$ for the locus $(d h)$. The low frequency of heterozygosity for both populations revealed a high fixation of alleles for each locus. Homozygote excess was observed in both populations. The values of Nei's genetic identity and the presence of loci with different allele frequencies in both populations may imply that the two populations belong to different species. The genetic variability between populations was compared to other data for loricariids.
\end{abstract}

Key words: allozymes, genetic variability, Neoplecostominae, Neotropical fishes.

Received: October 27, 2010; Accepted: March 30, 2011.

\section{Introduction}

The order Siluriformes is the most diverse and welldistributed within the Ostariophysi, and includes 3093 species, 478 genera and 36 families (Ferraris Jr, 2007). In the Neotropical region, there are 1648 nominal species grouped in 15 families (Reis et al., 2003). The distribution of Neotropical Siluriformes appears to be limited by temperature since most of the species live in tropical areas, with few reaching the southern portion of South America or the northern edge of North America (Nelson, 2006). Many species of this order occur in small headwater streams with clear water, strong currents and a high oxygen content, while others have adapted to stagnant and often polluted waters in which oxygen levels are extremely low (Burgess, 1989; M.R. Britto, 2002, Doctoral thesis, Universidade de São Paulo, São Paulo, Brazil). Among the headwater fishes of the southeastern region of South America, representa-

Send correspondence to Erasmo Renesto. Departamento de Biologia Celular e Genética, Universidade Estadual de Maringá, Av. Colombo, 5790, 87020-900 Maringá, PR, Brazil. E-mail: erenesto@ hotmail.com. tives of the subfamily Neoplecostominae are the most prominent.

There is controversy regarding which genera belong to the Neoplecostominae, although important progress has been made through the phylogenetic contributions of Montoya-Burgos et al. (1998), Cramer et al. (2008) and Chiachio et al. (2009). Within the Neoplecostominae, representatives of the genus Neoplecostomus occur in the headwater streams of southern and southeastern Brazil. Langeani (1990), who reviewed the genus Neoplecostomus, recognized $N$. microps and $N$. granosus, and described $N$. paranensis, $N$. espiritosantensis, $N$. ribeirensis and $N$. franciscoensis. Bizerril (1995) subsequently described $N$. variipictus from the Paraíba do Sul River basin, and Zawadzki et al. (2008a) recently described three new species of Neoplecostomus ( $N$. corumba, N. selenae and $N$. yapo) from the upper Paraná River basin.

Neoplecostomus species are morphologically very similar (Langeani, 1990), although some can be very different genetically, as shown by Zawadzki et al. (2004a), who compared Neoplecostomus corumba (Neoplecostomus sp. in that work) and $N$. paranensis using allozyme electropho- 
resis. In view of the difficulty in identifying species of this genus, in the present study, two populations of Neoplecostomus, one from São Domingos stream of the Grande River in the municipality of Muzambinho, in Minas Gerais State, and another from Paraitiguinha stream of the Tietê River basin in the municipality of Salesópolis, São Paulo State (both in the upper Paraná River basin) were compared using allozyme gel electrophoresis in order to improve our understanding of the biodiversity within this genus.

\section{Material and Methods}

Twenty-nine specimens of Neoplecostomus sp. 1 (Figure 1A) were collected in Paraitinguinha stream (Tietê River basin) at $23^{\circ} 30^{\prime} 39,84^{\prime \prime} \mathrm{S} / 45^{\circ} 51^{\prime} 32,22^{\prime \prime} \mathrm{W}$ and an altitude of 786 meters in the municipality of Salesópolis, São Paulo State (Figure 2). Twenty specimens of Neoplecostomus sp. 2 (Figure 1B) were collected in São Domingos stream (Grande River basin), 21 ${ }^{\circ} 20^{\prime} 47,22^{\prime \prime}$ $\mathrm{S} / 46^{\circ} 28^{\prime} 00,79^{\prime \prime} \mathrm{W}$ and an altitude of 1021 meters in the municipality of Muzambinho, Minas Gerais State (Figure 2). Specimens of the two populations reported here differed morphologically from the four species of Neoplecostomus described for the upper Paraná River basin by the following characters: (1) a well-developed adipose fin distinguished them from $N$. corumba and $N$. paranensis that have a reduced/absent adipose fin or no adipose fin, respectively, and (2) homogeneously dispersed hypertrophied odontodes in the dorsal region of the head and not bordered by swollen skin $v s$. more hypertrophied odontodes in front of the eyes

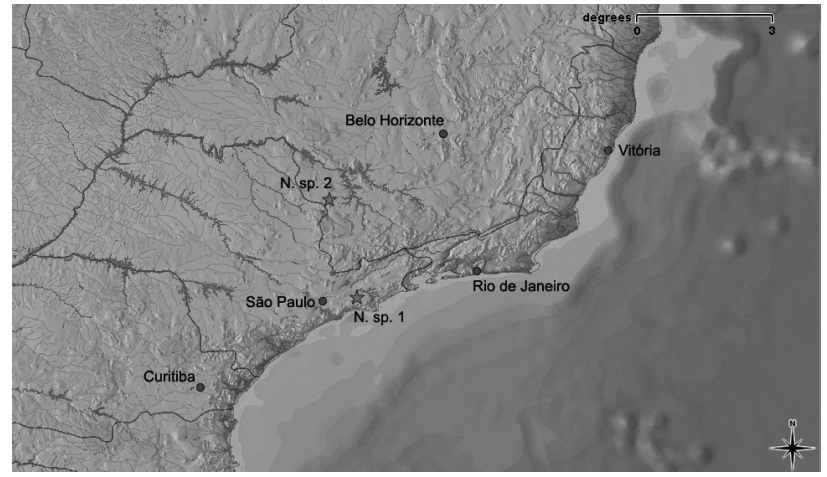

Figure 2 - Geographic location of sampling sites for Neoplecostomus sp. 1 (N. sp. 1) and Neoplecostomus sp. 2 (N. sp. 2).

and the lateral margin of the snout surrounded by swollen skin in N. selenae, and more hypertrophied odontodes bordered by hypertrophied skin only on the lateral margin of the snout in N. yapo.

The fish were frozen in liquid nitrogen and transported to the Universidade Estadual de Maringá. Voucher specimens were deposited in the ichthyological collection of the Núcleo de Pesquisas em Limnologia, Ictiologia e Aquicultura (Nupélia) of the Universidade Estadual de Maringá (Neoplecostomus sp. 1 under accession number NUP 6102 and Neoplecostomus sp. 2 under accession number NUP 6103).

Samples of liver and white muscle were homogenized with a plastic pestle in polypropylene tubes $(1.5 \mathrm{~mL})$ containing $100 \mu \mathrm{L}$ of $0.02 \mathrm{M}$ Tris-HCl, $\mathrm{pH}$ 7.5. To the liver samples $100 \mu \mathrm{L}$ of carbon tetrachloride $\left(\mathrm{CCl}_{4}\right)$ was added

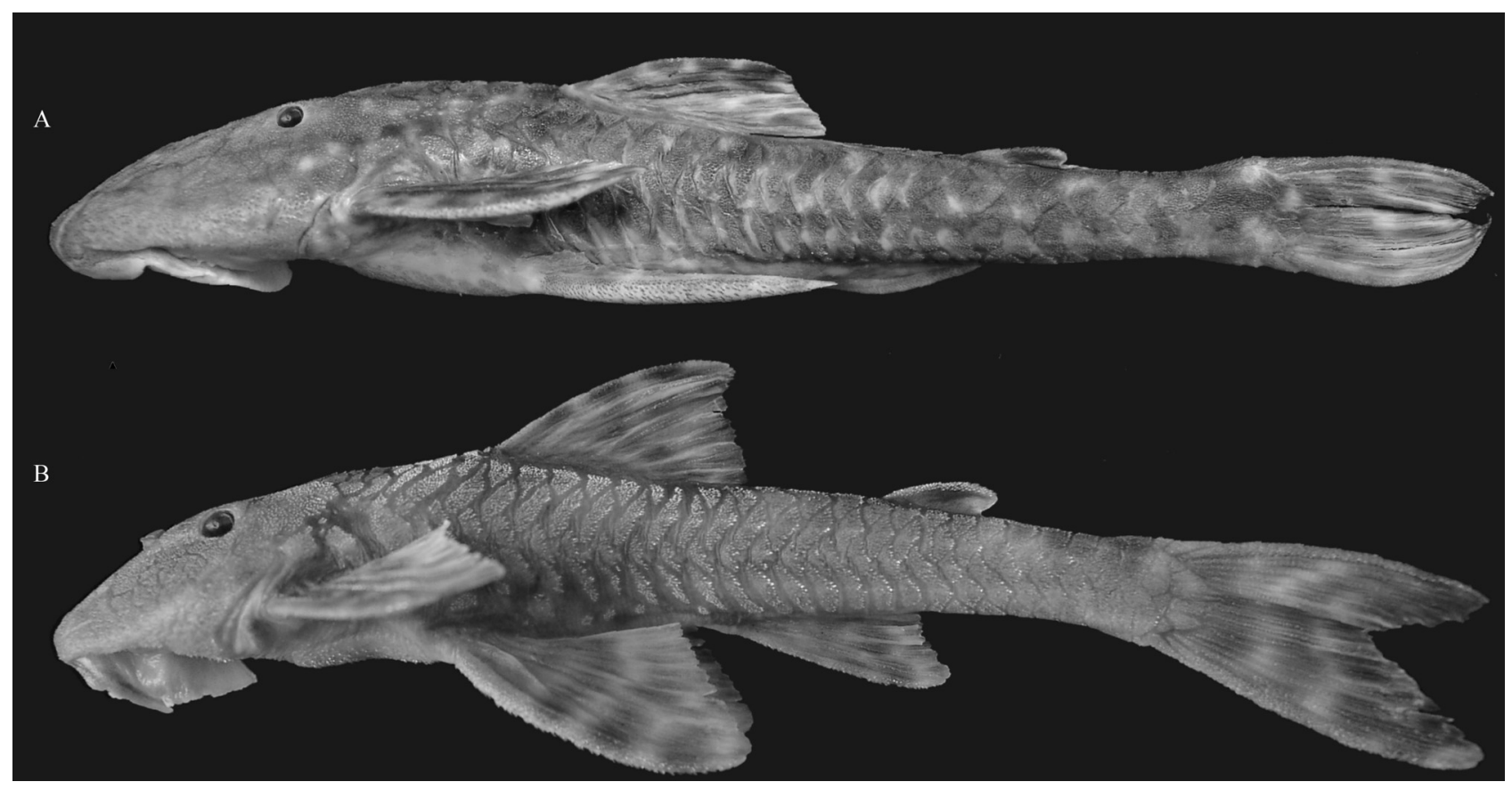

Figure 1 - A) Neoplecostomus sp. 1, CP = 102.2 mm, collected in the Paraitinguinha stream, Salesópolis, SP, NUP6103; B) Neoplecostomus sp. 2, CP = 75.2 mm, collected in São Domingos stream, Muzambinho, MG, NUP 6102. 
to facilitate homogenization of this fatty tissue (Pasteur et al., 1988). Aliquots of the protein extracts were applied to $15 \%$ corn starch (Penetrose 50) gels (Val et al., 1981) by using small (4 mm x $8 \mathrm{~mm}$ ) Whatman ${ }^{\mathbb{B}} 3 \mathrm{MM}$ filter paper strips soaked in the samples followed by horizontal electrophoresis under refrigeration. Two buffer solutions were used: $0.135 \mathrm{M}$ Tris $/ 0.043 \mathrm{M}$ citric acid, $\mathrm{pH} 7.0$ (TC), diluted 15 times during preparation of the gel, and $0.18 \mathrm{M}$ Tris/0.1 M boric acid/0.004 M EDTA, pH 8.6 (TBE), diluted four times during preparation of the gel.

The gels were run for $17 \mathrm{~h}$ (current of $\sim 50 \mathrm{~V}$ at the ends of the gel). After electrophoresis, the gels were cut horizontally into two slices that were then incubated with specific histochemical solutions to detect the bands of enzyme activity in each system, according to standard protocols (Murphy et al., 1996).

The genetic interpretation of the electrophoretic profiles was based on the structure of each enzyme, according to Ward et al. (1992). Genetic variability was estimated by calculating the expected (He) and observed (Ho) heterozygosities, according to Nei (1978), as well as genetic identity (I) and distance (D), which were calculated from the allele frequencies. All analyses were done using the software GENEPOP 1.31 (Yeh et al., 1997).

\section{Results}

We analyzed 12 enzyme systems (Table 1) in two populations of Neoplecostomus and obtained 19 loci (Table 2) with a total of 29 alleles. Of the 49 individuals analyzed, 29 belonged to the morphotype Neoplecostomus sp. 1, collected in Paraitinguinha stream, and 20 to Neoplecostomus sp. 2, collected in São Domingos stream. The elec-

Table 1 - Name, Enzyme Commission number (E.C. No.), tissue, buffer, and number of loci for each enzyme in Neoplecostomus sp. 1 from Paraitinguinha stream (Salesópolis, SP) and Neoplecostomus sp. 2 from São Domingos stream (Muzambinho, MG).

\begin{tabular}{lcccc}
\hline Enzyme (abbreviation) & E.C. No. & Tissue & Buffer & Loci \\
\hline Aspartate aminotransferase (AAT) & 2.6 .1 .1 & $\mathrm{~L}$ & TBE & 1 \\
Acid phosphatase (ACP) & 3.1 .3 .2 & $\mathrm{~L}$ & TBE & 1 \\
Alcohol dehydrogenase (ADH) & 1.1 .1 .1 & $\mathrm{~L}$ & $\mathrm{TBE}$ & 1 \\
Esterase (EST) & 3.1 .1 .1 & $\mathrm{~L}$ & $\mathrm{TBE}$ & 2 \\
Glycerol-3-phosphate dehydro- & 1.1 .1 .8 & $\mathrm{M}$ & $\mathrm{TC}$ & 2 \\
genase (G3PDH) & & & & \\
Glucose dehydrogenase (GDH) & 1.1 .1 .47 & $\mathrm{~L}$ & $\mathrm{TBE}$ & 1 \\
Isocitrate dehydrogenase (IDH) & 1.1 .1 .42 & $\mathrm{M}$ & $\mathrm{TC}$ & 1 \\
L-lactate dehydrogenase (LDH) & 1.1 .1 .27 & $\mathrm{M}$ & $\mathrm{TC}$ & 2 \\
Malate dehydrogenase (MDH) & 1.1 .1 .37 & $\mathrm{M}$ & $\mathrm{TC}$ & 3 \\
Peroxidase (PER) & 1.11 .1 .6 & $\mathrm{~L}$ & $\mathrm{TBE}$ & 2 \\
Phosphoglucomutase (PGM) & 5.4 .2 .2 & $\mathrm{M}$ & $\mathrm{TC}$ & 1 \\
Sorbitol dehydrogenase (SORB) & 1.1 .1 .14 & $\mathrm{~L}$ & $\mathrm{TC}$ & 2 \\
\hline
\end{tabular}

$\mathrm{L}$ - lier, $\mathrm{M}$ - muscle, TBE - Tris/borate/EDTA buffer, $\mathrm{pH} 8.7$ (Boyer et al., 1963) and TC - Tris/citrate buffer, pH 7.0 (Shaw and Prasad, 1970). trophoretic patterns of the 12 enzyme systems obtained in this study were similar to those reported by Zawadzki et al. (2004a).

The two populations differed at nine (Aat, Acp, Adh, Gdh, Idh, Mdh-C, Pgm and Sorb-1-2) of the 19 loci. These loci were diagnostic, i.e., they possessed alleles for each morphotype with a frequency of $100 \%$. As shown in Table 2, Neoplecostomus sp. 2 (from Muzambinho) was monomorphic at all 19 loci, whereas Neoplecostomus sp. 1 (from Salesópolis) was monomorphic at all but one locus $(5.26 \%$ polymorphism; only the $I d h$ loci showed allelic variation). The expected heterozygosity (He) for Neoplecostomus sp. 1 was 0.0069 , while the observed heterozygosity (Ho) was 0.0073 .

Table 2 - Allele frequencies at 19 loci in Neoplecostomus sp. 1 from Paraitinguinha stream (Salesópolis, SP) and Neoplecostomus sp. 2 from São Domingos stream (Muzambinho, MG).

\begin{tabular}{|c|c|c|c|}
\hline Loci & Alleles & Salesópolis $(\mathrm{N}=29)$ & Muzambinho $(\mathrm{N}=20)$ \\
\hline \multirow[t]{2}{*}{$A a t^{*}$} & $a$ & - & 1.0000 \\
\hline & $b$ & 1.0000 & - \\
\hline \multirow[t]{2}{*}{$A c p^{*}$} & $a$ & - & 1.0000 \\
\hline & $b$ & 1.0000 & - \\
\hline \multirow[t]{2}{*}{$A d h^{*}$} & $a$ & - & 1.0000 \\
\hline & $b$ & 1.0000 & - \\
\hline Est-1 & $a$ & 1.0000 & 1.0000 \\
\hline Est-2 & $a$ & 1.0000 & 1.0000 \\
\hline \multirow[t]{2}{*}{$G d h^{*}$} & $a$ & - & 1.0000 \\
\hline & $b$ & 1.0000 & - \\
\hline G3pdh-1 & $a$ & 1.0000 & 1.0000 \\
\hline G3pdh-2 & $a$ & 1.0000 & 1.0000 \\
\hline \multirow[t]{3}{*}{$I d h^{*}$} & $a$ & - & 1.0000 \\
\hline & $b$ & 0.9310 & - \\
\hline & $c$ & 0.0690 & - \\
\hline$L d h-A$ & $a$ & 1.0000 & 1.0000 \\
\hline$L d h-B$ & $a$ & 1.0000 & 1.0000 \\
\hline$M d h-A$ & $a$ & 1.0000 & 1.0000 \\
\hline$M d h-B$ & $a$ & 1.0000 & 1.0000 \\
\hline \multirow[t]{2}{*}{$M d h-C^{*}$} & $a$ & - & 1.0000 \\
\hline & $b$ & 1.0000 & - \\
\hline Per-1 & $a$ & 1.0000 & 1.0000 \\
\hline Per-2 & $a$ & 1.0000 & 1.0000 \\
\hline \multirow[t]{2}{*}{ Pgm* } & $a$ & 1.0000 & - \\
\hline & $b$ & & 1.0000 \\
\hline \multirow[t]{2}{*}{ Sorb-1* } & $a$ & - & 1.0000 \\
\hline & $b$ & 1.0000 & \\
\hline \multirow[t]{2}{*}{ Sorb-2* } & $a$ & - & 1.0000 \\
\hline & $b$ & 1.0000 & - \\
\hline
\end{tabular}

$\mathrm{N}=$ number of specimens analyzed. Asterisks indicate loci with allele frequencies that differed significantly between populations. 
Based on the gene frequencies, the genetic identity (I) and distance (D) were 0.5281 and 0.6384 , respectively. The Nei (1978) genetic distance represents the average number of nucleotide substitutions per locus (detectable by electrophoresis) that have accumulated in populations since they diverged from a common ancestor, i.e., the substitution is proportional to evolutionary time (Dobzhansky et al., 1977; Thorpe, 1982; Thorpe and Solé-Cava, 1994).

The negative value of $\mathrm{F}_{\text {IS }}(-0.0741)$ indicated an excess of heterozygotes for the Idh locus in the Neoplecostomus sp. 1 population. On the other hand, the mean $\mathrm{F}_{\text {IT }}$ value (0.9844) indicated an excess of homozygotes for both species. According to Wright (1978), the $\mathrm{F}_{\mathrm{ST}}$ statistic reflects genetic differentiation between two populations. The average $\mathrm{F}_{\mathrm{ST}}$ score for the loci analyzed was 0.9855 , indicating marked genetic differentiation between the two samples; for nine loci (Aat, Acp, Adh, Gdh, Mdhc, Pgm, Sorb-1 and Sorb-2) the $\mathrm{F}_{\mathrm{ST}}$ value was 1.00.

\section{Discussion}

According to Thorpe and Solé-Cava (1994), populations belonging to the same species have genetic identity values (I) $>0.85$, whereas those belonging to different genera have $\mathrm{I}<0.35$ and species belonging to the same genus have I values of $0.35-0.85$. The I value for Neoplecostomus sp. 1 and Neoplecostomus sp. 2 was 0.5281 (with $\mathrm{D}=0.6384$ ), indicating that these populations belong to two species of the same genus. Neoplecostomus species are morphologically very similar (Langeani, 1990), but very different genetically, as shown by Zawadzki et al. (2004a). The detection of fixed divergent alleles in syntopic populations of diploid organisms generally reflects a restricted gene flow and, consequently, the existence of different biological species (Richardson et al., 1986; Murphy et al., 1996). As shown here, nine of the 19 loci surveyed were diagnostic (Table 2), leading us to conclude that the two populations studied represented different species.

In contrast to the marked genetic divergence seen here between the two populations, other studies based on allozyme characters in allopatric populations of loricariid fishes have found no diagnostic markers. For example, Zawadzki et al. (2008b) found no fixed diagnostic markers for three populations of Hypostomus regani from the Corumbá River, Itaipu Reservoir (both in the upper Paraná River basin) and Manso River (in the Paraguay River basin). Similarly, Limeira et al. (2009) found no fixed markers in two populations of Rineloricaria pentamaculata above and below an $80 \mathrm{~m}$ high waterfall on the Ivaí River. Strieder et al. (2009) also found no fixed markers for four populations of $N$. yapo along tributaries of the Tibagi and Pirapó rivers. The lack of genetic divergence in these loricariid populations highlights the relevance of the marked differentiation seen between Neoplecostomus sp. 1 and Neoplecostomus sp. 2. The finding that almost half of the surveyed loci were fixed to different alleles in each pop- ulation suggests that there are strong geographic barriers to Neoplecostomus fish that try to move from the headwaters of the Tietê River basin to the headwaters of the Grande River basin, or vice versa. Since specimens of Neoplecostomus occur only in medium to small headwater streams, we believe that the main channel of large rivers such as the Tietê, Paraná and Grande acts as a barrier to free dispersion.

The finding that Neoplecostomus sp. 2 was monomorphic for the 19 loci while Neoplecostomus sp. 1 was polymorphic at only a single locus (Idh) contrasted with other studies in which the percentage of polymorphic loci in loricariids was generally greater than that observed here. Zawadzki et al. (2004a) reported that several loci (Gpi-B, $L d h-B$ and $P g m-A$ ) were polymorphic in a population of Neoplecostomus sp. $(=N$. corumba) whereas no polymorphism was observed in $N$. paranensis. Zawadzki et al. (1999) found that the percentage of polymorphic loci in three populations of Hypostomus from the Iguaçu River basin ranged from 20 to 40\%, whereas Paiva et al. (2005) detected $20 \%$ polymorphic loci in $H$. strigaticeps and Hypostomus sp. 1 and no polymorphism in Hypostomus sp. 2 from Ribeirão Maringá.

The He values in the family Loricariidae vary considerably. Zawadzki et al. (1999) found low He values of 0.011 in Hypostomus derbyi and 0.017 in H. myersi from the Iguaçu River basin, but an extremely high value $(\mathrm{He}=0.107)$ for another species of Hypostomus (Hypostomus sp.) from the Itaipu Reservoir in the Paraná River basin (Zawadzki et al., 2005). The $\mathrm{He}$ of Neoplecostomus sp. 1 in the present study was 0.0069 , a low value when compared to that observed by Zawadzki et al. (2004a) for Neoplecostomus sp. $(\mathrm{He}=0.030)$ and also low in relation to other loricariids from the Paraná-Paraguay River basin (Zawadzki et al., 2002, 2004b; Paiva et al., 2005; Renesto et al., 2007; Ito et al., 2009; Strieder et al., 2009). The He for the population of Neoplecostomus sp. 2 was zero, as also reported for $N$. paranensis from Hortelã stream (Zawadzki et al., 2004a). The genetic variability in Neoplecostomus sp. 1 and Neoplecostomus sp. 2 is low when compared to the average He of 0.051 estimated for 195 species of different fish species around the world (Ward et al., 1992).

According to Zawadzki et al. (2004a), the unusual absence of allozyme genetic variability in $N$. paranensis from Hortelã stream could be explained by the endogamic process and ecological restrictions imposed by geographical or environmental barriers to species of Neoplecostomus. Likewise, in the present study, the low levels of genetic variability for the two populations of Neoplecostomus may indicate that they are mainly sedentary and probably restricted to small areas.

Loricariids are generally non-migratory (Burgess, 1989; Montoya-Burgos, 2003). Moreover, the short length of most Neoplecostomus species and the currently re- 
stricted distribution of their populations (limited to headwaters) point towards a low rate of migration (Chiachio et al., 2008). The sedentary nature of these fish leads to mating within the same family group and results in low genetic variability. These characteristics suggest a possible restricted range and reduced gene flow among Neoplecostomus species compared to other fish species. A reduction in gene flow and genetic events, such as inbreeding, may favor rapid speciation and endemism (Strieder et al., 2009). In addition, other evolutionary forces may also affect Neoplecostomus species. For example, stochastic events such as genetic drift could lead to the fixation of alternative alleles (Kerr and Wright, 1954) in these presumably small populations and may provide a reasonable explanation for the low intraspecific and high interspecific variation in Neoplecostomus species. Our findings suggest that other genetically-differentiated populations may be revealed as more headwater streams in southeastern Brazil are sampled.

\section{Acknowledgments}

The authors thank Guilherme Costa e Silva and Renato Devidé for helping to collect the specimens, Suzana Paiva for helping with laboratory experiments, Nupélia (Núcleo de Pesquisas em Limnologia, Ictiologia e Aquicultura) for logistical support and Anderson L. Alves for reading and reviewing this manuscript. We also thank Corn Products Brazil for supplying Penetrose 50. This work was partially supported by Conselho Nacional de Desenvolvimento Científico e Tecnológico (CNPq, grant no. 484716/20996-9) and by an individual grant to Claudio Henrique Zawadzki (CNPq grant no. 306066/2009-2).

\section{References}

Bizerril CRSF (1995) Descrição de uma nova espécie de Neoplecostomus (Loricariidae, Neoplecostominae), com uma sinopse da composição taxonômica dos Loricariidae no leste Brasileiro. Arq Biol Tecnol 38:693-704.

Boyer SH, Fainer DC and Naughton MA (1963) Myoglobin inherited structural variation in man. Science 140:1228-1231.

Burgess WE (1989) An Atlas of Freshwater and Marine Catfishes: A Preliminary Survey of the Siluriformes. TFH Publications, Neptune, 784 pp.

Chiachio MC, Oliveira C and Montoya-Burgos JI (2008) Molecular systematics and historical biogeography of the armored Neotropical catfishes Hypoptopomatinae and Neoplecostominae (Siluriformes, Loricariidae). Mol Phyl Evol 49:606-617.

Cramer CA, Liedke AMR, Bonatto SL and Reis RE (2008) The phylogenetic relationship of the Hypoptopomatinae and Neoplecostominae (Siluriformes, Loricariidae) as inferred from mitochondrial cytochrome c oxidase I sequences. Bull Fish Biol 9:51-59.

Dobzhansky T, Ayala FJ, Stebbins GL and Valentine JW (1977) Evolution. W.H. Freeman, San Francisco, 572 pp.
Ferraris Jr CJ (2007) Checklist of catfishes, recent and fossil (Osteichthyes, Siluriformes), and catalogue of siluriform primary types. Zootaxa 1418:1-628.

Ito KF, Renesto E and Zawadzki CH (2009) Biochemical comparison of two Hypostomus populations (Siluriformes, Loricariidae) from the Atlântico Stream of the upper Paraná River basin, Brazil. Genet Mol Biol 32:51-57.

Kerr WE and Wright S (1954) Experimental studies of the distribution of gene frequencies in very small populations of Drosophila melanogaster. I-III. Evolution 8:172-177, 225240, 293-202.

Langeani F (1990) Revisão do gênero Neoplecostomus Eigenmann \& Eigenmann, 1888, com a descrição de quatro espécies novas do sudeste brasileiro (Siluriformes, Loricariidae). Comum Mus Ciênc PUCRS Sér Zool 3:3-31.

Limeira DM, Renesto E and Zawadzki CH (2009) Allozyme comparison of two populations of Rineloricaria (Siluriformes, Loricariidae) from the Ivaí River, upper Paraná River basin, Brazil. Genet Mol Biol 32:431-435.

Montoya-Burgos JI (2003) Historical biogeography of the catfish genus Hypostomus (Siluriformes, Loricariidae), with implications on the diversification of Neotropical ichthyofauna. Mol Ecol 12:1855-1867.

Montoya-Burgos JI, Muller S, Weber C and Pawlowski J (1998) Phylogenetic relationships of the Loricariidae (Siluriformes) based on mitochondrial rRNA gene sequences. In: Malabarba LR, Reis RE, Vari RP, Lucena ZMS and Lucena CAS (eds) Phylogeny and Classification of Neotropical Fishes. Editora da Pontifícia Universidade Católica do Rio Grande do Sul, Porto Alegre, pp 363-374.

Murphy RW, Sites Jr JW, Buth DG and Haufler CH (1996) Proteins: Isozyme electrophoresis. In: Hillis DM, Moritz C and Mable BK (eds) Molecular Systematics. 2nd edition. Sinauer Associates, Massachusetts, pp 51-120.

Nei M (1978) Estimation of average heterozygosity and genetic distance from a small number of individuals. Genetics 89:583-590.

Nelson JS (2006) Fishes of the World. 4th edition. John Wiley and Sons, New York, 550 pp.

Paiva S, Renesto E and Zawadzki CH (2005) Genetic variability of Hypostomus (Teleostei, Loricariidae) from the Ribeirão Maringá, a stream of the upper Rio Paraná basin, Brazil. Genet Mol Biol 28:370-375.

Pasteur N, Pasteur G, Bonhomme F, Catalan J and Britton-Davidian J (1988) Practical Isozyme Genetics. Ellis Horwood, Chichester, pp 215.

Reis RE, Kullander SO and Ferraris Jr CJ (2003) Checklist of the Freshwater Fishes of South America. Edipucrs, Porto Alegre, $729 \mathrm{pp}$.

Renesto E, Zawadzki CH and Revaldaves E (2007) Allozyme differentiation and relationships within Hypostomus Lacépède, 1803 (Osteichthyes, Loricariidae) from the upper Paraguay River basin, Brazil. Biochem Syst Ecol 35:869-876.

Richardson BJ, Baverstock PR and Adams M (1986) Allozyme Electrophoresis: A Handbook for Animal Systematics and Population Studies. Academic Press, Sydney, 409 pp.

Shaw CR and Prasad R (1970) Starch gel electrophoresis - A compilation of recipes. Biochem Genet 4:297-320.

Strieder JP, Renesto E, Gealh AM, Artoni RF, Shibatta OA and Zawadzki CH (2009) Genetic variability in four samples of 
Neoplecostomus yapo (Teleostei, Loricariidae) from the Rio Paranapanema basin, Brazil. Neotrop Ichthyol 7:25-30.

Thorpe JP (1982) The molecular clock hypothesis: Biochemical evolution, genetic differentiation and systematics. Annu Rev Ecol Syst 13:139-168.

Thorpe JP and Solé-Cava AM (1994) The use of allozyme electrophoresis in invertebrate systematics. Zool Scripta 23:3-18.

Val AL, Schwantes AR, Schwantes MLB and Luca PH (1981) Amido hidrolisado de milho como suporte eletroforético. Cienc Cult 33:992-996.

Ward RD, Skibinski DOF and Woodward M (1992) Protein heterozygosity, protein structure, and taxonomic differentiation. Evol Biol 26:73-157.

Wright S (1978) Evolution and Genetics of Populations. The University of Chicago Press, Chicago, 465 pp.

Zawadzki CH, Renesto E and Bini LM (1999) Genetic and morphometric analysis of three species of the genus Hypostomus Lacépède, 1803 (Osteichthyes, Loricariidae) from the Rio Iguaçu basin (Brazil). Rev Suisse Zool 106:91-105.

Zawadzki CH, Weber C, Pavanelli CS and Renesto E (2002) Morphological and biochemical comparison of two allopatrid populations of Hypostomus margaritifer (Regan, 1907) (Osteichthyes, Loricariidae) from the upper Paraná River basin, Brazil. Acta Scient 24:499-505.

Zawadzki CH, Alves AL, Renesto E and Oliveira C (2004a) Biochemical evidence of a possible new species of Neoplecostomus (Teleostei, Loricariidae) from the upper Rio Paraná basin, Brazil. Biochem Syst Ecol 32:573-582.
Zawadzki CH, Renesto E, Paiva S and Lara-Kamei MCS (2004b) Allozyme differentiation of four populations of Hypostomus (Teleostei, Loricariidae) from Ribeirão Keller, a stream in the upper Rio Paraná basin, Brazil. Genetica 121:251-257.

Zawadzki CH, Renesto E, Reis RE, Moura MO and Mateus RP (2005) Allozyme relationships in hypostomines (Teleostei, Loricariidae) from the Itaipu Reservoir, upper Rio Paraná basin, Brazil. Genetica 123:271-283.

Zawadzki CH, Pavanelli CS and Langeani F (2008a) Neoplecostomus (Teleostei, Loricariidae) from the upper Rio Paraná basin, Brazil, with description of three new species. Zootaxa 1757:31-48.

Zawadzki CH, Renesto E, Peres MD and Paiva S (2008b) Allozyme variation among three populations of the armored catfish Hypostomus regani (Ihering, 1905) (Siluriformes, Loricariidae) from the Paraná and Paraguay river basins, Brazil. Genet Mol Biol 31:767-771.

\section{Internet Resource}

Yeh FC, Yang R-C, Boyle TBJ, Ye Z-H and Mao JX (1997) POPGENE, the user-friendly shareware for population genetic analysis. Molecular Biology and Biotechnology Centre, University of Alberta, Canada. http://www.ualberta.ca/ fyeh/faq.htm (Abril 29, 2009).

Associate Editor: Fábio de Melo Sene

License information: This is an open-access article distributed under the terms of the Creative Commons Attribution License, which permits unrestricted use, distribution, and reproduction in any medium, provided the original work is properly cited. 